\title{
Research on Commercial Bank Logistics Financial Business Risk in China
}

\author{
Zhao Yanni* \\ Yunnan University Dianchi College \\ Kunming, China \\ 324040828@qq.com \\ * Corresponding Author
}

\author{
Feng Zhiyong \\ School of economics, Yunnan University \\ Kunming, China \\ 99627085@qq.com
}

\begin{abstract}
Interaction and mutual demand between logistics and financial institutions lead to constant development of logistics financial business with rapid development of logistics industry in China. All major commercial banks begin to develop logistics financial business, and logistics financial business belongs to emerging business in China. Commercial Banks in China actively develop logistics financial business due to earning drive. Market environment is immature, and commercial banks are lack of experience in developing logistics financial business. Huge risks are hidden in logistics financial business in China commercial banks. Therefore, logistics financial business of commercial banks is studied in the paper, logistics financial connotation, present situation of development and main risks are analyzed, and strategies of preventing risks are proposed. In the paper, it is believed that the credit evaluation system should be established and improved; the relevant laws and regulations should be perfected; operation risk is controlled from the aspects of process, personnel, etc., and warehouse receipt pledge management should be strengthened, thereby lowering logistics financial business risks of China commercial banks, and promoting long-term development of commercial bank logistics financial business.
\end{abstract} risk

Keywords-commercial banks; logistics finance; business

\section{DEVELOPMENT SITUATION OF COMMERCIAL BANK LOGISTICS FINANCIAL BUSINESS IN CHINA}

\section{A. Connotation of logistics finance}

Logistics finance provides good platform for interindustry tight cooperation among supply chain enterprises, financial institutions and third-party service supplier. Therefore, cooperation can reach "win-win" effect. Logistics finance refers to financial business of providing logistics industry with fund financing, settlement, insurance and other service financial services. It is accompanied by development of logistics industry. Logistics finance mainly involves three subjects, namely logistics enterprise, financial institution and client. Figure 1 shows logistics financial connotation drawing. It is obvious from the figure that logistics enterprises and financial institutions are combined to provide financing for enterprises with fund requirement. Development of logistics finance has urgent realistic demand on the three parties. Close integration of logistics and finance can powerfully support social commodity circulation, thereby promoting smooth circulation system reform [1-3]. Logistics finance is becoming an important financial business of domestic bank, and its role is gradually revealed.

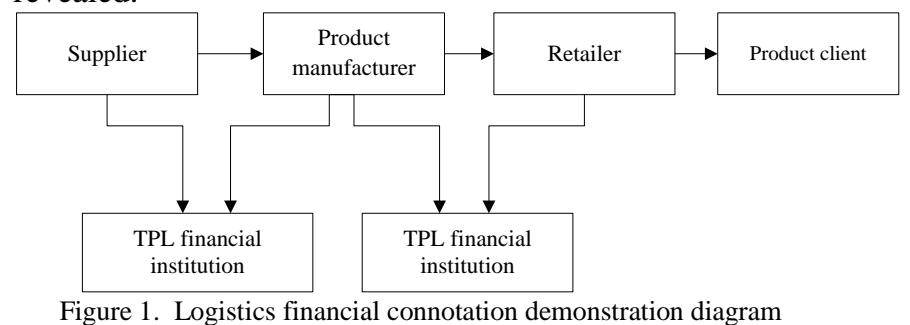

\section{B. Logistics financial business development situation of} domestic commercial bank

Commercial banks in China started to provide logistics financial services at the beginning of the 21 st century. It provided warehousing services at the initial stage, which is later developed into financing services. Logistics finance of China commercial banks is developed slowly due to influence of environment in China with low market share. Logistics finance of China commercial banks is improved through being developed for several years. China CITIC Bank and Shenzhen Development Bank are commercial banks with rapider development of logistics financial business. Currently, a relatively complete financial logistics service system has been formed in China. Logistics financial business of other domestic commercial banks has also made certain progress. In the paper, logistics services business of several typical commercial banks is analyzed.

\section{1) China CITIC Bank}

China CITIC Bank Qingdao Branch launches 'Portshipping Financing' and 'Supervision Financing' services. These businesses are outstanding in many 'logistics finance' business by their innovative and professional features. China CITIC Bank is mainly engaged in steel and iron financial service, therefore steel and iron enterprises can get more financial support and good market reaction [4-5].

\section{2) Shenzhen Development Bank}

It is the first bank in China to provide inventory impawn financing business. Before the business is launched, it is widely popular among logistics enterprises. The assets for mortgage or pledge are free from flaw. Logistics financial products become low risk and high income symbols in financial services provided by the bank through long-term development.[6-8] 


\section{3) Industrial and Commercial Bank of China}

Financial services of other banks are analyzed by Industrial and Commercial Bank of China. On the basis, Industrial and Commercial Bank of China signs contract with state-owned large logistics enterprises, thereby providing financial services for the enterprises. Meanwhile, Industrial and Commercial Bank of China also signed related cooperation agreement with other competent logistics enterprises in the aspect of business development [9].

\section{4) China Merchants Bank}

China Merchants Bank launched 'Dianjin Logistics Finance' Products in 2008. Demands of domestic and foreign enterprises are comprehensively analyzed under the condition. In addition, a series of products with wide coverage and considerate services are provided according to the analysis. The personalized design service is popular among small and medium-sized enterprises [10].

The above commercial banks obtain better achievements in the aspect of logistics financial business. Currently, commercial banks of many cities have gradually entered logistics financial field. However, logistics financial services are still in traditional business field with less personalized services. In addition, risk prevention of commercial banks to logistics financial business is not mature enough with more risks, thereby affecting longterm development of commercial bank logistics finance.

\section{LOGISTICS FINANCIAL RISKS OF COMMERCIAL} BANKS

China logistics financial business is constantly developed with rapid economic development in China. Logistics financial risk and business risk of commercial banks are increased, thereby seriously affecting long-term analysis of logistics financial business in commercial banks. Logistics finance risks of commercial banks mainly include the following aspects:

\section{A. Credit risk}

In China, research duration on credit risk in our country time is not long. Unified and reasonable credit risk evaluation system is not established by the state. Meanwhile, laws and systems of related industry are not perfectly established. Economic development speed is too fast, and systems are insufficient. Law guarantee coverage is smaller, thereby leading to trade credit loss. Finally, logistics finance industry can be developed into industry bank with more credit risks. It is more unbeneficial for development of commercial banks. Logistics finance industry is a third party economic development mode independent from commercial financial development and financing enterprise. Main risks should be assumed by logistics enterprises. Both parties have entrustment relationship for logistics enterprise. Firstly, logistics enterprises only can play the role of data collection and delivery for financing enterprise. When data in financing enterprise are false or missing, logistics enterprises do not have recognition and correction ability. Therefore, errors are discovered in credit appraisal of commercial banks on financing enterprises, thereby finally leading to financing failure. Secondly, risk prevention of commercial banks to logistics enterprise can be lowered due to specialty of logistics enterprise. The above two problems are caused due to insufficient responsibility sense and weak professionalism

Logistics finance of commercial banks also suffers from loan risk rating index failure risk. Loan credit of many commercial banks in China is realized mainly through hierarchical management, mainly including: actual situation of loan project, current market development trend, actual economic condition of financing enterprise, operation condition of enterprises applying for loan, financing orientation, purpose, bank credit of financing enterprise, and whether financing loan behavior is protected by law or not. Since more economic entities participate in development during development of logistics finance industry. Some commercial banks specially deliver credit appraisal right of financing enterprise to logistics enterprises. However, logistics enterprises do not have own professional credit appraisal system, thereby credit risks can be increased, and development risk of commercial banks is increased. Meanwhile, great influence can be produced on financing enterprises.

\section{B. Legal risks}

Development speed of China logistics industry is too fast. However, many related systems have not yet been established. The industry is in loose state as a whole. Meanwhile, commercial banks do not have unified and clear requirement in the operation process. Many important bills and articles are not legally protected. There are less information sharing platforms between logistics enterprise and participant. 'Property Law' has limited management ability on the development of logistics industry, which can not meet long-term development of logistics finance industry. If perfect legal system can not be established as soon as possible, logistics financial industry will encounter many legal risks which can not be controlled.

\section{Operation risk}

Logistics finance operation risks of commercial banks mainly include three aspects: firstly, when commercial bank and logistics enterprise appraise credit related certificates submitted by financing enterprises, high requirements are proposed on appraisers. However, development time of logistics enterprises is too short. Enterprises are not provided with professional credit appraisal personnel inside. Credit appraisal of logistics enterprises on financing enterprises has great manipulation space. Secondly, there is no unified system or regulation on contract standard and credit business flow of commercial banks. It is possible to implement fraud behavior. Thirdly, analysis on financing risk is not supported by related analysis control system in the process of approving loan for financing enterprise. Risk analysis error can be easily produced, thereby leading to enterprise financing failure.

\section{Warehouse receipt pledge loan risk}

Warehouse receipt pledge loan refers that goods owner enterprises store goods in warehouses. Warehouse should issue goods warehousing voucher, which is used for applying loan from the bank. Banks provide loan to the goods owner according to warehouse goods value. Commercial bank loan leads to warehouse receipt risk, commodity selection risk and commodity supervision risk 
to goods owner enterprise. (1) Warehouse receipt risk, warehouse receipt can be pledged to the bank as negotiable securities, which can realize capital financing. Warehouse receipt is important proof and legal basis for developing warehouse receipt pledge business. However, there is no uniform use form of warehouse receipt in China. Different warehouses can design warehouse receipts by themselves, thereby increasing the difficulty of banks to recognize and manage logistics enterprise warehouse receipt. When some warehouses apply for pledge loan from the banks, they do not issue effective warehouse receipts, warehousing entries and inventory sheets are applied, thereby increasing logistics financial business risk of commercial banks. (2) Commodity selection risk: many commodities are not suitable for pledge mainly because quality and price of many commodities are greatly fluctuated over time. If pledged commodities are not selected properly, collateral will be depreciated, and thereby the loan amount obtained by enterprises can be higher than the value of collateral. Certain logistics financial risks can be produced. (2) Commodity supervision risk: since warehouse information is not symmetrical to bank information. Information lag may be produced in the aspect of pledge commodity regulation, thereby leading to decision-making errors of banks and warehouses. Currently, though logistics enterprises have established warehouse management information system, working efficiency is improved, enterprises can be effectively supervised, they still have disadvantages in business flow, client data collection, etc., thereby leading to threat to pledged commodity supervision, and producing logistics financial risks to commercial banks.

\section{LOGISTICS FINANCIAL RISK PREVENTION STRATEGY OF COMMERCIAL BANKS}

\section{A. Establishment of sound credit evaluation system}

Chinese commercial banks should establish and improve credit evaluation system. First of all, management ability and credit situation of cooperation logistics enterprises are appraised for comprehensively comprehending customer management condition and credit information, and investigating client repayment history and contract performance ability. Commercial banks do not cooperate with clients with worse credit record. Secondly, evaluation index of logistics enterprises is optimized, and credit risk quantitative model is established. When commercial banks appraise logistics enterprises and financing enterprises, commercial banks can insist on principle of combining qualitative and quantitative indexes. Quantitative factors of loan classification standards can be scientifically and rationally selected. Logistics enterprise operating performance, management scale, bank credit, manufacturing enterprise business intimacy and other appraisal indicators are properly added. Credit audit risk can be lowered. Finally, non-monetary punishment debt contracts should be established, commercial banks should adhere to the principle of incentive compatibility. Non-monetary punishment can be added to logistics enterprise through debt contracts, thereby ensuring truth and integrity of information provided by logistics enterprises. Such modes can alleviate risk of commercial banks, and business management advantages of logistics enterprise can be exerted.

\section{B. Perfection of relevant laws and regulations}

Related laws and regulations should be perfected in order to prevent logistics financial risk of commercial banks. Firstly, existing legal systems can be perfected, financial legislation should be strengthened, 'Deposit Insurance Regulations', 'Regulations on Credit Investigation Management' and 'Regulations on Foreign Exchange Administration' should be formulated and perfected. Law enforcement and supervision should be reinforced for resolving administrative dispute. Administrative reconsideration duties should be preformed for protecting lawful rights and interests; secondly, policies and regulations supporting logistics finance should be established for gradually perfecting risk prevention system of logistics finance elites. Relevant legal rules about pledge, pledge right, pledge right assignment, loans, financial guarantee, etc. are gradually perfected, thereby achieving legal compliance. Commercial bank logistics financial business access, operation guidance, industry management measures as well as other related laws and regulation are perfected. Finally, supervision legal system of small and medium-sized banks should be strengthened. Small and medium-sized enterprises play important promotion role to economic development in China. There are more medium and small banks in China, which provide financial services of small and medium-sized logistics enterprises. Therefore, China should improve financial supervision legal system guided by small and mediumsized enterprises for effectively supervising financial risks of small and medium-sized bank logistics, thereby increasing security and stability of the financial system.

\section{Control of operation risk from flow, personnel and other aspects}

Improper operation is one of important factors to logistics finance risk in commercial banks. Therefore, commercial banks should prevent operation risk from the aspects of bank system, flow, personnel, etc. Firstly, commercial bank financial business process should be perfected, internal control system should be perfected, credit asset management department can be set, credit management personnel and marketing personnel should audit twice with mutual supervision, thereby lowering logistics financial operation risks, the collateral warehousing, outbound, price change and other conditions of logistics enterprises are monitored, hidden danger can be timely discovered, logistics financial risk of commercial bank can be lowered. Secondly, overall quality of operation personnel should be improved, and risk awareness and professional ethics of operation personnel should be improved. Logistics financial business is compared with traditional credit business. More complicated information should be investigated before loan is lent. Commercial banks not only need to improve quality of operation personnel, but also should establish and perfect audit template, transfer investigation, post-loan operation guidance, etc., therefore business personnel can collect information according to concrete requirement. Operation flow can be carried out according to regulated operation steps. Risk points should be specially focused, 
thereby lowering operation risk of logistics financial business in commercial banks.

\section{Reinforcement of warehouse receipt pledge management}

Commercial banks should reinforce warehouse receipt pledge management and prevent warehouse receipt pledge loan risk. Firstly, commercial banks should establish credibility with clients, and bank pledge loan business should be implemented on the basis of real and effective warehouse receipt as well as trust of supervision warehouse of logistics enterprises. Therefore, credit establishment is actually based on the strength of logistics enterprises. Logistics enterprises can implement warehouse receipt pledge business through relationship trusted by both parties, thereby completing credit integrity. Secondly, warehouse receipt management should be strengthened, warehouse receipt operation procedures should be perfected, fixed warehouse receipt format should be regulated, and special personnel should be entrusted for warehouse receipt management, receipt replacement and pledge termination. Pledge warehouse receipt can be issued and determined in the form of document. Finally, pledged commodity management should be reinforced, commodity pledged in the bank can be circulated, but firstin and first-out of inventory goods should be ensured. Meanwhile, it should be ensured that the value of inventory after being discounted according to determined proportion is not lower than the credit limit provided by the bank to the distributor. The seller should be responsible for the quality of the pledged goods during goods pledge. After the loan is lent, both parties should regularly count the collateral, account and physical goods should be checked. Banks can entrust warehouse management personnel to control goods access of the warehouse. If the seller can not return bank loan on schedule, banks have the right to auction goods, thereby repaying loan, acceptance receivable and other losses.

\section{SUMMARY}

Logistics financial business is not developed in China commercial banks for long term. Since China logistics industry is rapidly developed, logistics financial business of commercial banks has wide development prospects. Logistics financial business of China commercial banks have more problems and hidden risks due to influence of own factors and external environment factors of commercial banks. Analysis and study in the paper discover that commercial bank logistics financial business mainly has credit risk, operational risk, legal risk and warehouse receipt pledge loan risk. In the paper, it is believed that credit evaluation system should be established and perfected. Relevant laws and regulations should be perfected; operation risks should be controlled from the aspect of flow, personnel, etc., and warehouse receipt pledge management should be strengthened. Therefore, logistics financial business operation risks of commercial banks can be lowered, which is beneficial or realizing win-win situation of many parties, including commercial bank, logistics enterprises as well as small and medium-sized enterprises.

\section{REFERENCES}

[1] Lu Hualan. "Countermeasures for optimization of urban commercial bank logistics financial business," Market Modernization, 2013, vol. 31, pp. 76-78.

[2] Wang Ni. "Research on logistics financial business risk of China commercial bank," Journal of Hubei Economy Academy (Humanities and Social Science Edition), 2012 , vol. 7, pp. 31-34.

[3] Feng Haixia, Cui Jianxin, Hu Guihua. "Research on risk prevention of logistics financial business implemented in China commercial banks," Logistics Engineering and Managemen, 2012 , vol. 3, pp. 17-19.

[4] Yang Fengmei, Mao Sixing. "Research on risk and countermeasures of implementing logistics financial business in China," National Business (Economic Theory Research), 2009 , vol. 5, pp. 125-126.

[5] Wang Hanxiao. "Research and risk and countermeasures of implementing emerging logistics financial business," Jiangxi Social Science, 2011 , vol. 3, pp. 95-96.

[6] Gao Feng, Geng Zhen, Lin Gang. "Discussion on logistics financial development mode in China," Market Modernization, 2012 , vol. 5, pp. 22-23.

[7] Tang Yuanyuan. "Discussion on logistics financial value and risk," Business Manager, 2012 , vol. 5, pp. 37-38.

[8] Wan Yuanyuan. "Research on present situation and its mode selection of China logistics finance development," Value Engineering, 2012 , vol. 5, pp. 103-105.

[9] An Yuxue. "Probing into China commercial bank risk m anagem ent countermeasure," Special Zone Economy, 2012 , vol. 2, pp. 85 87.

[10] Qian Jun. "Construction of the Overall Risk Managing Model:Measures of Commercial Bank Risk Management Process,' Journal of Huaihai Institute of Technology(Social Science Edition), 2011 , vol. 1, pp. 17-19. 